\title{
Cellular and Nerve Fibre Catecholaminergic Thymic Network: Steroid Hormone Dependent Activity
}

\author{
G. LEPOSAVIĆ ${ }^{1,2}$, I. PILIPOVIĆ ${ }^{1}$, M. PERIŠIĆ ${ }^{1}$ \\ ${ }^{1}$ Immunology Research Centre "Branislav Janković", Institute of Virology, Vaccines and Sera \\ “Torlak", Belgrade, Serbia, ${ }^{2}$ Department of Physiology, Faculty of Pharmacy, University of \\ Belgrade, Belgrade, Serbia
}

Received November 30, 2010

Accepted February 17, 2011

On-line July 19, 2011

\section{Summary}

The thymus plays a critical role in establishing and maintaining the peripheral T-cell pool. It does so by providing a microenvironment within which $\mathrm{T}$-cell precursors differentiate and undergo selection processes to create a functional population of major histocompatibility complex-restricted, self-tolerant $\mathrm{T}$ cells. These cells are central to adaptive immunity. Thymic T-cell development is influenced by locally produced soluble factors and cell-to-cell interactions, as well as by sympathetic noradrenergic and endocrine system signalling. Thymic lymphoid and nonlymphoid cells have been shown not only to express $\beta$ - and $a_{1}$ - adrenoceptors (ARs), but also to synthesize catecholamines (CAs). Thus, it is suggested that CAs influence T-cell development via both neurocrine/endocrine and autocrine/ paracrine action, and that they serve as immunotransmitters between thymocytes and nerves. CAs acting at multiple sites along the thymocyte developmental route affect T-cell generation not only numerically, but also qualitatively. Thymic CA level and synthesis, as well as AR expression exhibit sex steroid-mediated sexual dimorphism. Moreover, the influence of CAs on T-cell development exhibits glucocorticoid-dependent plasticity. This review summarizes recent findings in this field and our current understanding of complex and multifaceted neuroendocrineimmune communications at thymic level.

\section{Key words}

Thymus • Catecholamines • Adrenoceptors • Sexual dimorphism - Glucocorticoids

\section{Corresponding author}

G. Leposasavić, Department of Physiology, Faculty of Pharmacy, University of Belgrade, 450 Vojvode Stepe, 11221 Belgrade, Serbia. E-mail: Gordana.Leposavic@pharmacy.bg.ac.rs

\section{Introduction}

It is well known that the brain and immune system, as major adaptive systems, communicate with each other extensively in order to maintain body homeostasis. This communication involves the autonomic nervous system, mainly its sympathetic branch, and the hypothalamo-pituitary-adrenal axis (Madden and Felten 1995, Besedovsky and Del Rey 1996, Fabris et al. 1997, Mocchegiani et al. 2006, Haddad 2008). The key node in brain-immune system crosstalk is the thymus, the primary lymphoid organ responsible for T-cell development (Dardenne and Savino 1996, Fabris et al. 1997, Thyagarajan and Felten 2002, Mocchegiani et al. 2006). The thymus receives information from both the brain and circulating lymphocytes (Madden and Felten 1995, Fabris et al. 1997, Mocchegiani et al. 2006). Lymphocytes were suggested to act as the body's sixth sense transmitting information, via the thymus or directly, to the brain about responses to external or internal antigenic stimuli (Blalock 1994).

There is increasing evidence that immune system cells, including thymic lymphoid and nonlymphoid cells, are capable of synthesizing and releasing not only cytokines, but also neuropeptides, 
neurotransmitters and hormones, and expressing specific receptors for these agonists (Batanero et al. 1992, Bergquist et al. 1994, Dardenne and Savino 1996, Josefsson et al. 1996, Silva et al. 2006, Pilipović et al. 2008). Thus, coexisting in the nervous, endocrine and immune systems, these agonists provide the universal language of the neuro-endocrine-immune network. This enables the nervous, endocrine and immune systems to regulate and fine-tune their functional responses, and consequently allow the body to adapt to changes in the internal and external environments. Understanding the functional interactions among these three systems, and their relevance to various physiological processes, is needed: (i) to recognize the mechanisms underlying the onset and course of many pathologic conditions related to immune system disturbances, such as infective, autoimmune/inflammatory and neoplastic diseases, and (ii) to envisage therapeutic strategies to counteract their onset and/or progress. This review is focused on depicting the histotopography of thymic catecholamines (CAs), and elucidating the putative significance of CA-steroid hormone interactions, in particular between $\mathrm{CA}$ and glucocorticoids (GCs), in fine-tuning T-cell development and consequently immune responses.

\section{Catecholamine sources in the thymus}

\section{Thymic noradrenergic innervation}

The thymus receives extensive sympathetic innervation (Williams and Felten 1981, Felten et al. 1985, Novotny et al. 1990, Vizi et al. 1995, Cavallotti et al. 1999, Nance and Sanders 2007). Thus, noradrenergic nerve profiles were identified not only along the vasculature in the subcapsular and associated septal regions, but also in close apposition to thymocytes and thymic epithelial cells (TECs) (Leposavić et al. 1992, Vizi et al. 1995). In the outer cortex, TECs forming the blood-thymus barrier are also exposed to circulating noradrenaline (NA). In addition, noradrenergic nerve profiles, including their varicose terminals, were observed in close proximity to mast cells, fibroblasts and macrophages (Novotny et al. 1990, Vizi et al. 1995). However, classical synapses between these nerve profiles and thymic cells were not detected. It was assumed that NA releases nonsynaptically from free nerve endings into a large extraneuronal space with no postjunctional specializations (Novotny et al. 1990, Vizi et al. 1995). Thus, most likely, NA diffuses a considerable distance before interacting with its receptors on target cells (Vizi and Labos 1991). It is also strongly believed that NA released from perivascular or connective tissue septa plexuses diffuses away through surrounding adventitia or collagenous fibrils, in a paracrine fashion, transmitting a signal to thymic cells (Elenkov et al. 2000). Moreover, nonsynaptic transmission occurs in thymic blood vessel walls (between varicose nerve terminals and smooth muscle cells), where NA is involved in the regulation of blood flow and lymphoid cell traffic (Elenkov et al. 2000).

Generally, NA is released in the thymus in response to axonal firing arising in the central nervous system. This release is subjected to presynaptic modulation by various endogenous ligands (e.g. NA, adrenaline, acetylcholine, adenosine, etc.) or different drugs from the circulation through various receptors $\left(\alpha_{2}-\right.$ ARs, N-nicotinic, $\mathrm{P}_{1}$-purinergic and prostaglandin $\mathrm{E}$ presynaptic receptors) (Hasko et al. 1995).

\section{Thymic cells}

Much evidence gathered during the past 15 years indicates that, besides neuronal and endocrine cells, many types of immune cells synthesize and secrete CAs. By acting in an autocrine/paracrine manner they regulate many immune functions, including cellular proliferation, differentiation, apoptosis and cytokine production. (Bergquist et al. 1994, Josefsson et al. 1996, Cosentino et al. 2000, Jiang et al. 2006). Recently, we detected NA in rat thymocytes, whereas dopamine content was below the reliably measurable level (Leposavić et al. 2007, 2010, Pilipović et al. 2008). Given that tyrosine hydroxylase $(\mathrm{TH})$, the rate limiting enzyme in CA synthesis, was found in these cells at both the protein (Leposavić et al. 2007, 2010, Pilipović et al. 2008) and mRNA levels (Fig. 1), it seems highly conceivable that thymocytes not only take up NA passively from their microenvironment, but also synthesize it. The lack of measurable dopamine in thymocytes coincides with the finding that NA represents the major portion (57-95\%) of intracellular CAs in lymphocytes (Cosentino et al. 2000). A possible explanation for differential amount of NA and dopamine in lymphocytes is that, quite opposite to the rate of synthesis, the secretion rate of NA in lymphocyte cultures is lower than that of dopamine (Qiu et al. 2005). Flow cytometry analysis revealed $\mathrm{TH}$ immunostaining across all thymocyte subsets delineated by $\mathrm{CD} 3$ surface density, but the greatest frequency of TH-immunoreactive (ir) cells was registered within the most mature $\mathrm{CD} 3^{\text {high }}$ thymocyte subset (Pilipović et al. 2008). In agreement 
with this finding, TH-ir thymocytes occurred most frequently on the medullary side of the cortico-medullary junction, although they were also present in the subcapsular cortex, and rarely intracortically and intramedullary (Pilipović et al. 2008). Furthermore, mRNA for phenylethanolamine N-methyltransferase, which converts NA to adrenaline, was also found in rodent thymi (Andreassi et al. 1998, Warthan et al. 2002). The specific cell types expressing mRNA for this enzyme have not yet been identified. We failed to detect adrenaline in rat thymocytes (Leposavić et al. 2007, Pilipović et al. 2008).

In the rat thymus, morphologically diverse subsets of non-lymphoid cells were also shown to contain immunoreactive TH (Leposavić et al. 2007, Pilipović et al. 2008). Their distribution pattern roughly matches that of thymocytes, i.e. they densely populate the medullary side of the cortico-medullary junction, moderately the subcapsular cortex, but are extremely rare intracortically and intramedullary. Immunocytochemical staining of rat and human thymic sections and/or isolated TEC-enriched thymic stromal cell fractions showed TH expression in neural crest derived thymic nurse cells (Jones et al. 1998, Botham et al. 2001, Pilipović et al. 2008). These cells formed multicellular complexes with thymocytes and macrophages completely enclosed within their cytoplasm (Pezzano et al. 2001). They may be involved in thymocyte positive selection and early post-selection development, as well as clearance of thymocytes, which were negatively selected or dying from neglect (Pezzano et al. 2001). Namely, in thymic nurse cells were identified $\mathrm{CD} 4+\mathrm{CD} 8+$ double positive (DP) TCR $\alpha \beta^{\text {low }}$ thymocytes. These cells derive from CD4-CD8-TCR $\alpha \beta$ triple negative precursors following successful rearrangement of genes encoding $\alpha$ and $\beta$ TCR chains, and successive surface expression of TCR $\alpha \beta$ complex and CD4 and CD8 coreceptor molecules. To proceed further with development, DP TCR $\alpha \beta^{\text {low }}$ thymocytes are obliged to interact with self-peptides associated with major histocompatibility complex (MHC) antigens expressed on the surface of thymic non-lymphoid cells, and, most likely, on the vacuole surface surrounding engulfed thymocytes in thymic nurse cells (McCormack et al. 1991, Pezzano et al. 2001). At present, the most scrutinized hypothesis proposes that thymocytes producing a TCR $\alpha \beta$ that binds either tightly or not bind to self-peptide in association with MHC antigens are selectively deleted (Marrack and Kappler 1988, McCormack et al. 1991). On the other hand, thymocytes producing a TCR $\alpha \beta$ that binds self-peptide with low affinity are allowed to mature to CD4+ or CD8+ single positive (SP) cells, and are ultimately released from the thymus (Marrack and Kappler 1988, McCormack et al. 1991). Immunoreactive TH was also found within some other types of TECs, possibly type 1 and type 5 TECs (Kranz et al. 1997, Anagnostou et al. 2007, Pilipović et al. 2008). Macrophages in the subcapsular/subtrabecular cortex and at the cortico-medullary junction also showed TH immunoreactivity (Leposavić et al. 2008).

These findings indicate that in thymus, apart from the catecholaminergic nerve fibre network, there is cellular catecholaminergic network comprising lymphoid and non-lymphoid cells, whose functional significance still awaits full appreciation.

\section{Expression of adrenoceptors in the thymus}

Although the expression of both $\beta_{1}$ - and $\beta_{2}$-ARs has been found in rat thymus, $\beta_{2}$-ARs appears to be the major $\beta$-AR subtype in this tissue (Marchetti et al. 1990a,b, 1994). We observed $\beta_{2}$-AR-ir cells mainly in the subcapsular/subtrabecular cortex and the corticomedullary junction, but extremely rarely in the medulla (Leposavić et al. 2008, 2010). Expression of $\beta_{2}$-ARs was demonstrated on both thymocytes and thymic nonlymphoid cells, and TH was found in some of them as well (Leposavić et al. 2008). Compared to mature $\mathrm{T}$ lymphocytes, thymocytes expressed fewer $\beta_{2}$-ARs per cell, with the exception of the most mature cells (Fuchs et al. 1988). This suggests that $\beta_{2}$-AR expression on thymocytes is developmentally regulated.

Using double immunocytochemical staining with antibodies specific for $\beta_{2}$-AR and pan-cytokeratin, we found that subsets of TECs located mainly in the cortico-medulla exhibit $\beta_{2}$-AR immunoreactivity (Leposavić et al. 2008). Apart from $\beta_{2}$-ARs, functional studies demonstrated $\beta_{1}$ - ARs on TECs. In addition, it was shown that NA may directly inhibit TEC proliferation and cytokine secretion or modulate the efficacy of other stimuli (Kurz et al. 1997, von Patay et al. 1999). Macrophages in the subcapsular cortex and cortico-medullary junction also exhibit $\beta_{2}$-AR immunoreactivity (Leposavić et al. 2008). Thus, it seems plausible to conclude that CAs, via $\beta$-ARs, influence T-cell development directly and indirectly, modulating their microenvironment.

Data on the presence of $\alpha$-ARs on T cells are rather limited (Kavelaars 2002). Both $\alpha_{1}$-AR mRNA and 
$\alpha_{1}$-AR protein were demonstrated in human bone marrow cells and thymocytes and in rat thymocytes, respectively (Kavelaars 2002, Pešić et al. 2009, Leposavić et al. 2010). Expression of $\alpha_{1}$-ARs in human peripheral blood mononuclear cells was undetectable or extremely low (van der Voort et al. 2000a, Kavelaars 2002). Thus, one may speculate that $\alpha_{1}$-AR expression is downregulated during lymphocyte development (Kavelaars 2002). In agreement with this hypothesis our data show that a majority of $\alpha_{1}$-AR positive thymocytes are the least mature CD3-cells (Pešić et al. 2009). Given that bone marrow cells and CD3- thymocytes are proliferating as well as differentiating cells, whereas peripheral blood mononuclear cells are mainly in a resting stage (Kavelaars 2002), it may be further speculated that the developmental changes in $\alpha_{1}$-AR expression are associated with cellular activity. Support for this assumption comes from several line of evidence. First, $\alpha_{1}$-AR mRNA expression is higher in Con A-activated T lymphocytes than in the corresponding resting lymphocytes (van der Voort et al. 2000b, Bao et al. 2007). Second, the expression of $\alpha_{1}$-AR re-appears in secondary lymphoid organs, when lymphocytes start to proliferate and differentiate into effector cells (Kavelaars 2002). In rat thymus, non-lymphoid cells located subcapsulary/subtrabeculary, in the cortico-medullary junction and rarely intramedullary also express $\alpha_{1}$-ARs (Pešić et al. 2009). Further characterization of these cells demonstrated that: i) they belong either to TECs or CD68-positive macrophages and ii) some of them also express TH (Pešić et al. 2009). Thus, it may be assumed that $\alpha_{1}$-ARs are involved not only in intercellular thymic communication, but also in thymic non-lymphoid cell autoregulation.

\section{Receptor-independent intracellular catechol- amine action}

The agonistic actions of CAs are terminated by their inactivation via intracellular oxidation. During this process they are degraded into various products including large quantities of reactive oxygen species and other cytotoxic oxidative metabolites, which induce apoptosis in mouse lymphocytes, and PC12 cell lines (Josefsson et al. 1996, Burke et al. 1998). Newly synthesized CAs that are stored inside the cells could also cause oxidative stress-mediated receptor-independent apoptosis (Cosentino et al. 2003). Even more importantly, a CAspecific transporter was found on lymphocyte nuclear membranes (Bergquist et al. 1997, 2000). It actively transports CAs from the cytoplasm into the cell nucleus, where they can interact with nuclear steroid receptors and nuclear factor NF- $\kappa \mathrm{B}$ influencing transcription processes and modulating apoptosis (Bergquist et al. 1997, 2000). Thus, it may be assumed that CAs may influence T-cell development also via non-AR mediated mechanisms.

\section{Gonadal steroid-dependent sexual dichotomy in thymic NA levels and AR expression}

\section{Noradrenaline}

NA levels were higher in male than in female rat thymi (Pilipović et al. 2008). Considering that CAs are involved in modulating T-cell development (Rauški et al. 2003a,b, Leposavić et al. 2006, Pešić et al. 2009), it may be hypothesized that sexual dimorphism in thymic weight, cellularity and thymocyte subset distribution (Leposavić et al. 1996), at least partly, reflects gender dichotomy in thymic NA availability. Furthermore, since T-cells are central to adaptive immunity, it has been speculated that the observed sexual difference in the efficiency of the immune response establishes during T-cell development (Kovacs and Olsen 1998, AnsarAhmed et al. 1999). To elucidate mechanisms underlying sexual dimorphism in thymic NA level, we explored the density of noradrenergic nerve fibres and $\mathrm{TH}$ synthesizing thymic cells (Pilipović et al. 2008). There was no difference between male and female rats in the density of thymic noradrenergic nerve fibres (Pilipović et al. 2008), while the axonal NA content has not been measured. However, the densities of TH-ir lymphoid and non-lymphoid cells were greater in male than in female rats (Pilipović et al. 2008). In addition, TH mRNA (Fig. 1) and NA content (Pilipović et al. 2008) were greater in male than in female rat thymocytes. This agrees with data that in male rats nerve growth factor selectively and independently of neuronal proliferation induces synthesis of $\mathrm{TH}$ and dopamine $\beta$-hydroxylase (Thoenen and Barde 1980).

To establish any sex steroid contribution to the sexually dimorphic thymic NA level, we explored the effects of bilateral gonadectomy in male and female rats on thymic NA level (Pilipović et al. 2008). This was performed at the age of 30 days given that: i) sexual dimorphism in immune response efficiency and frequency of immune pathology arises soon after sexual maturation (Blazkovec and Orsini 1976) and ii) the hormonal changes occurring at the time of puberty lay the 
A
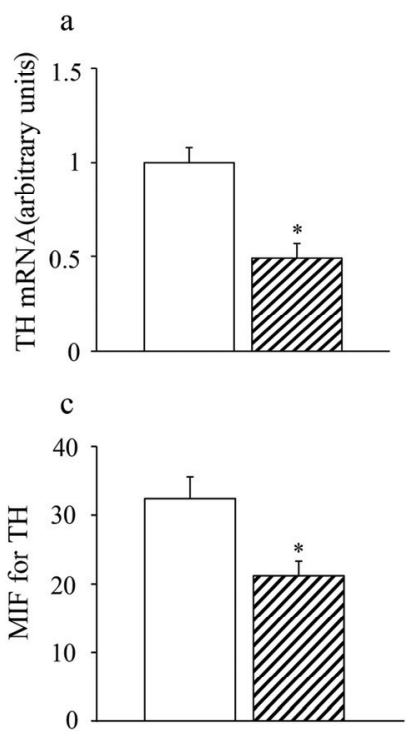

$\mathrm{TH}$

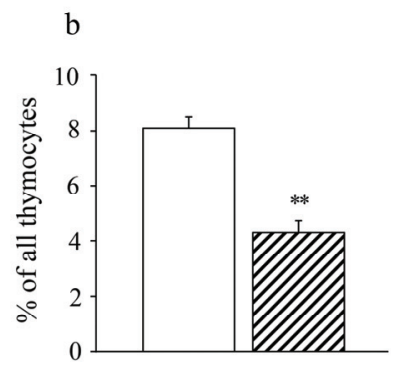

$\square$ Male
$\square$ Female
B
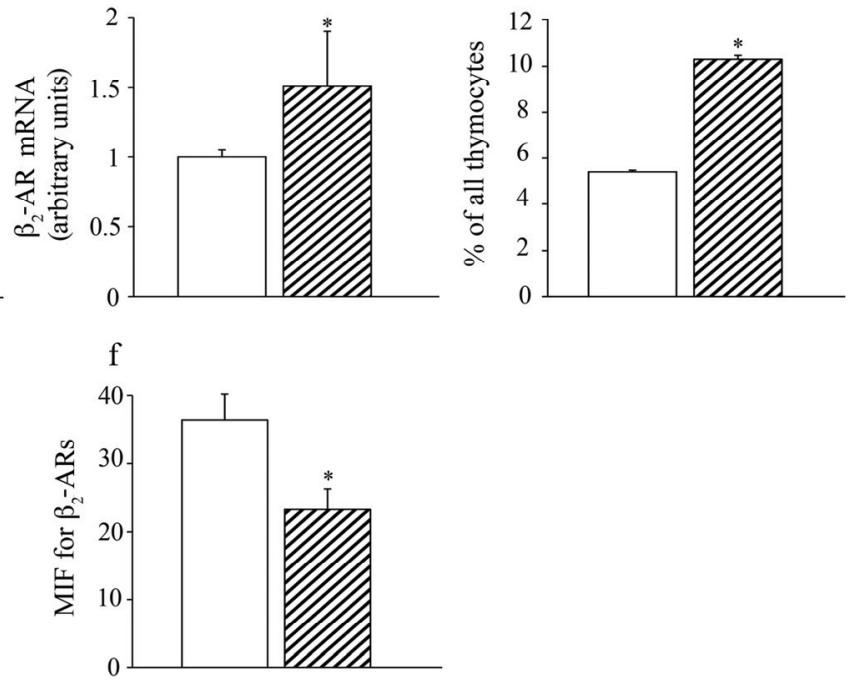

Fig. 1. Gender differences in thymocyte tyrosine hydroxylase (TH) and $\beta_{2}$-adrenoceptor $\left(\beta_{2}\right.$-AR) expression. $A$, Gender differences in (a) TH mRNA expression (as determined by real time RT-PCR), (b) frequency of TH containing thymocytes and (c) mean intensity of fluorescence (MIF) for TH, reflecting the thymocyte TH content (as measured by flow cytometry using monoclonal antibodies against rat TH and FITC-conjugated goat anti-mouse IgG antibody). B, Gender differences in (d) $\beta_{2}$-AR mRNA expression (as determined by real time RT-PCR), (e) frequency of $\beta_{2}$-AR bearing thymocytes and (f) MIF for $\beta_{2}$-AR reflecting $\beta_{2}$-AR thymocyte surface density (as measured by flow cytometry using policlonal antibodies against rat $\beta_{2}$-AR and FITC-conjugated goat anti-rabbit IgG antibodies).

framework for biological differences that persist throughout life (Da Silva 1999). Gonadectomy diminished NA levels in thymi from adult rats of both sexes, but to a greater extent in males. Therefore, in gonadectomised rats we failed to measure any gender differences in thymic NA level (Pilipović et al. 2008). Irrespective of sex, the decrease in thymic NA levels in gonadectomised rats reflected the reduced density of both NA-containing fibres and cells (Pilipović et al. 2008). Support for these conclusions comes from data showing that: i) in male rats $\mathrm{TH}$ activity in the hypogastric (Melvin and Hamill 1986) and pelvic ganglion (Melvin and Hamill 1987) rises in parallel with plasma testosterone level during postnatal development (Resco et al. 1968), and ii) oestrous cycle-, pregnancy- and ovariectomy-related hormonal changes coincide with alterations in the $\mathrm{TH}$ level in the superior cervical ganglion of female rats (Anglin and Brooks 2003).

\section{Adrenoceptors}

We also found sexual dimorphism in $\beta_{2}$-AR thymocyte surface expression (Fig. 1). Namely, although the $\beta_{2}$-AR mRNA level was greater in thymocyte suspensions from female than male rats, the surface density of $\beta_{2}$-ARs was less on female thymocytes reflecting the greater frequency of $\beta_{2}$-AR bearing cells in their suspensions than in corresponding suspensions from male rats (Fig. 1). These findings are corroborated by autoradiographic studies showing a sexually dimorphic pattern of postnatal changes in density of $\beta$-ARs in rat thymus (Marchetti et al. 1990b). Furthermore, it was found that alterations in gonadal steroid level influence $\beta_{2}$-AR thymocyte surface density in female (Marchetti et al. 1994). Moreover, $\beta_{2}$-AR stimulated activity of adenylyl cyclase was also shown to be dependent on the sex steroid hormone background (Marchetti et al. 1994). Thus, it may be assumed that gonadal steroids modulate the catecholaminergic influence on the thymus, affecting both availability of NA and/or density and functionality of $\beta_{2}$-ARs. On the other hand, data on the influence of gonadal steroids on $\alpha_{1}$-AR density and signalling capacity are still lacking.

\section{Catecholamine-mediated effects on T-cell development}

\section{Role of $\beta$-adrenoceptors}

There is accumulating clinical (Galbiati et al. 2007) and experimental evidence (Singh 1985a,b, Alaniz et al. 1999) suggesting a role for CAs in maintaining thymic size and T-cell output. To elucidate the mechanism underlying the influence of CAs on these parameters, the effects of long-lasting treatment with non-selective $\beta$-AR blockers on thymopoiesis were 
investigated (Leposavić et al. 2000, 2006, Madden and Felten 2001, Pešić et al. 2007). Although $\beta$-AR blockade did not affect overall thymic cellularity, it significantly influenced the T-cell development (Leposavić et al. 2000, 2006, Madden and Felten 2001, Pešić et al. 2007). Thymocytes undergoing selection appeared to be particularly sensitive to $\beta$-AR blockade (Leposavić et al. 2006, Pešić et al. 2007). Long-lasting treatment with propranolol, a non-selective beta-blocker, diminished the frequency of DP TCR $\alpha \beta^{\text {low }}$ cells entering selection processes. This decrease, coupled with the increased frequency of DP TCR $\alpha \beta^{\text {high }}$ cells that had just passed positive selection, and their SP $(\mathrm{CD} 4+\mathrm{CD} 8-$ and CD4CD8+cells) TCR $\alpha \beta^{\text {high }}$ descendents, strongly suggested enhanced positive/reduced negative selection and facilitated maturation of the selected cells. This in turn leaded to enhanced generation (Leposavić et al. 2006, Pešić et al. 2007), and probably subsequent egress of mature $\mathrm{T}$ cells into the periphery. Two lines of evidence associated alterations in thymocyte selection following propranolol treatment with the increase in Thy-1 surface density on selectable thymocytes (Leposavić et al. 2006, Pešić et al. 2007). First, it was shown that exogenous cAMP and NA can induce a decrease in steady state Thy-1 mRNA levels in T-lineage cells and murine thymocytes (Wajeman-Chao et al. 1998), which can be prevented by propranolol (Wajeman-Chao et al. 1998). Second, exaggerated negative selection and consequently markedly reduced de novo production of mature SP cells were found in Thy- $1^{-/}$mice (Hueber et al. 1997), and hence Thy-1 was implicated in the regulation of TCRdependent thymocyte selection (Killeen 1997).

\section{$\alpha_{1}$-adrenoceptors}

Differently from long-lasting blockade of $\beta$-ARs, long-term treatment with urapidil, an $\alpha_{1}$-AR antagonist, augmented thymocyte proliferation and increased thymocyte yield (Plećaš-Solarović et al. 2005, Pešić et al. 2009, Leposavić et al. 2010). As simultaneous administration of NA and propranolol decreased the frequency of proliferating cells in rat spleen (Stevenson et al. 2001), a stimulatory influence of urapidil on thymocyte proliferation was assumed (Pešić et al. 2009, Leposavić et al. 2010). In addition, urapidil affected the thymocyte phenotype profile and increased the frequency of DP TCR $\alpha \beta$ - thymocytes (Pešić et al. 2009, Leposavić et al. 2010). In the absence of changes in the frequency of precedent CD4-CD8- TCR $\alpha \beta$ - cells, this increase was related to a greater density of proliferating cells in the outer cortex of thymi from urapidil-treated than from control rats. Prolonged cell proliferation at the DP TCR $\alpha \beta$ - developmental stage is likely to postpone TCR $\alpha$ gene rearrangement ( $\mathrm{Xi}$ et al. 2006), and to impede transition to the next DP TCR $\alpha \beta^{\text {low }}$ developmental stage. Accordingly, the diminished frequency of DP TCR $\alpha \beta^{\text {low }}$ cells following urapidil treatment was attributed to decelerated differentiation of DP TCR $\alpha \beta$ - thymocytes (Pešić et al. 2009, Leposavić et al. 2010). The unaltered frequency of DP TCR ${ }^{\text {high }}$ thymocytes (being intermediary cells between the DP TCR $\alpha \beta^{\text {low }}$ and SP TCR $\alpha \beta^{\text {high }}$ stages), in conjunction with greater Thy-1 thymocyte surface density (reflecting a decline in central sympathetic flow caused by urapidil central action) in young adult rats, suggested more efficient positive/reduced negative thymocyte selection (Pešić et al. 2009). The greater Thy-1 thymocyte surface density in these rats, most likely, was associated with a decline in central sympathetic flow caused by urapidil central action (Pešić et al. 2009). The lack of urapidil influence on Thy1 expression in old rats indicated that urapidil might also influence the thymocyte selection via direct thymic action (Leposavić et al. 2010). This is fully consistent with the observation of Bellinger et al. (2008) that CAs acting via $\alpha_{1}$-ARs on TECs involved in thymocyte selection may affect thymopoiesis. Moreover, irrespective of age, urapidil influenced thymocyte lineage commitment, causing an increase in the frequency of CD4+CD8$\mathrm{TCR} \alpha \beta^{\text {high }}$ and a decrease in that of CD4-CD8+TCR $\alpha \beta^{\text {high }}$ SP cells (Pešić et al. 2009, Leposavić et al. 2010).

\section{Catecholamine-glucocorticoid interplay in the modulation of $\mathrm{T}$-cell development}

Repeated and chronic stress has an important role in the pathogenesis of almost all diseases related to immune system disturbances. Both GCs and CAs participate not only in regulating body functions during steady states, but also, often acting in concert, have a central role in maintaining the steady state of the internal milieu when it is threatened or disturbed by various internal or external challenges (Cunnick et al. 1990, Dobbs et al. 1993). Having this in mind, understanding their interplay in immunomodulation seems to be of utmost importance.

It has been shown that thymic lymphoid and non-lymphoid cells produce GCs and express glucocorticoid receptors (Lechner et al. 2000, Qiao et al. 2009). Furthermore, GCs have been implicated in the 
modulation of thymocyte development (Stojić-Vukanić et al. 2009). Moreover, they were shown to influence CA biosynthesis and release (Hagerty et al. 2001) and $\beta$ - and $\alpha_{1}$-AR gene expression (Cotecchia and De Blasi 1984). Based on these observations, we hypothesized that CA effects on thymopoiesis depend on the GC milieu (Pilipović et al. 2010). To test this we compared thymocyte development in rats adrenalectomized (Adx) four days before starting four-day-long propranolol treatment $(0.4 \mathrm{mg} / 100 \mathrm{~g}$ body weight/day, s.c. $)$ with that in non-Adx propranolol-treated rats. Generally, we found that $\beta$-AR blockade was more efficient in Adx rats than in non-Adx rats (Fig. 2) (Pilipović et al. 2010). This is corroborated by data that simultaneous administration of isoproterenol and hydrocortisone produces additive effects on many thymic indices (Durant 1986). Compared with non-Adx rats, we registered a more pronounced increase in frequency of the most mature SP (CD4+CD8and $\mathrm{CD} 4-\mathrm{CD} 8+) \mathrm{TCR} \alpha \beta^{\text {high }}$ thymocytes in Adx rats, which, most probably reflected more efficient positive/less efficient negative selection (Fig. 2). Given that GCs augment $\mathrm{CA}$ synthesis and $\beta$-AR expression (Cotecchia and De Blasi 1984, Hagerty et al. 2001), it was speculated that the alterations in thymopoiesis were related to diminished thymic CA availability and $\beta$-AR expression (Pilipović et al. 2010). However, when compared with non-Adx rats, propranolol caused unproportional increase in the frequency of the most mature SP cells in Adx rats (i.e. a more pronounced increase in the frequency of $\mathrm{CD} 8+\mathrm{CD} 4-$ than in that of CD8-CD4+ SP cells) (Fig. 2). Thus, it was clear that the differential effect of propranolol in Adx and non-Adx rats could not be solely explained by the more efficient $\beta$-AR blockade in Adx rats (Fig. 2). Considering the effects of $\alpha_{1}$-AR blockade on T-cell differentiation (Pešić et al. 2009, Leposavić et al. 2010), we supposed that more efficient $\alpha_{1}$-AR-mediated mechanisms in Adx rats contributed to this phenomenon (Fig. 2). To support this assumption are data that prolonged exposure of cardiac myocytes to NA diminishes $\alpha_{1}$-AR expression (Rokosh et al. 1996). Thus, in propranolol-treated $\mathrm{Adx}$ rats an increased $\alpha_{1}$-AR density, and consequently sensitivity of $\alpha_{1}$-AR-mediated mechanisms, reflecting diminished sympathetic NA outflow induced by central propranolol action (Mora et al. 1983) and reduced intrathymic CA synthesis (Hagerty et al. 2001) could be expected (Fig. 2).

Taken together, these data indicate that catecholaminergic modulation of thymopoiesis exhibits a substantial degree of GC-dependent plasticity (Fig. 2).

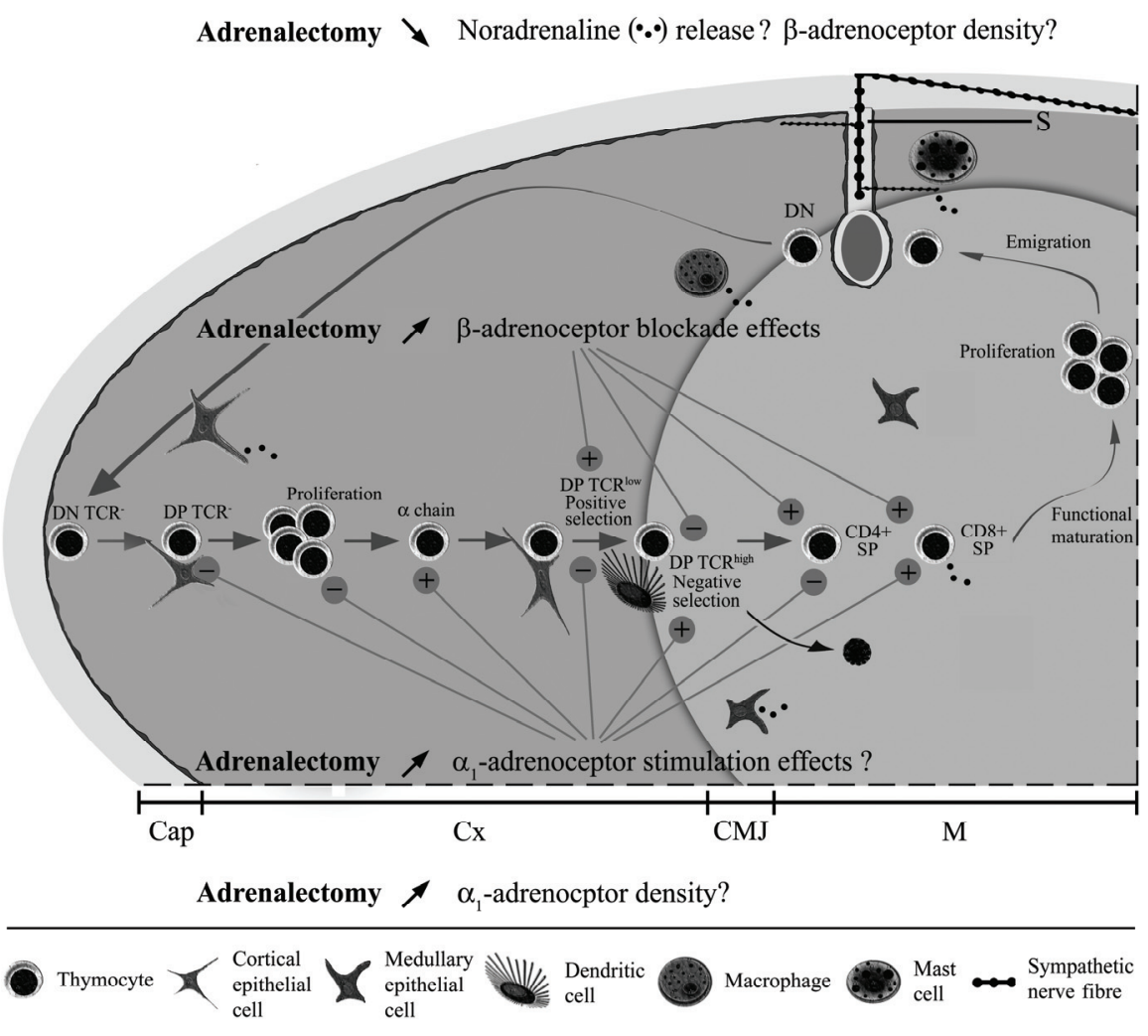

Fig. 2. Schematic representation of putative effects of $\beta$-adrenoceptor blockade with propranolol $(0.4 \mathrm{mg} / 100 \mathrm{~g}$ body weight/day, s.c.) on thymocyte differentiation in adult rats adrenalectomized four days before starting propranolol administration. Adrenalectomy, most probably, diminishing availability of noradrenaline derived from noradrenergic nerve fibres and thymic cells, and density of thymic $\beta$-adrenoceptors, augments efficiency of $\beta$-adrenoceptor blockade, and thereby increases thymocyte positive/decreased negative selection, and consequently frequency of the most mature single positive (SP) TCRa $\beta^{\text {high }}$ thymocytes. In addition, following propranolol treatment in adrenalectomized rats increased density of thymic $a_{1}$ adrenoceptors, and consequently efficiency of $a_{1}$-adrenoceptor-mediated mechanisms leading to the increase in the frequency of $\mathrm{CD} 4-\mathrm{CD} 8+\mathrm{TCR} a \beta^{\text {high }}$ and the decrease in that of CD4+CD8TCRa $\beta^{\text {high }}$ cells is likely to occur. Thus, the net effect of propranolol administration in adrenalectomized rats is favoured CD8 over CD4 cell differentiation/maturation leading to a more pronounced increase in frequency

of CD4-CD8+SP TCRa ${ }^{\text {high }}$ compared with that of CD4+CD8-SP TCRa $\beta^{\text {high }}$ cells. Symbols and abbreviations: $\lambda$, increase; $\downarrow$, decrease; Cap, capsule, Cx, cortex; CMJ, cortico-medullary junction; M, medulla; S, interlobulary septa; DN, double negative; DP, double positive. 


\section{Conclusions}

The findings collected to date indicate that subsets of thymic lymphoid and non-lymphoid cells also synthesize CAs, which together with CAs delivered by neural and endocrine cells, act either directly or indirectly on thymocytes at distinct stages of maturation, and consequently modulate thymic T-cell output not only numerically, but also qualitatively. Furthermore, they showed that there is sexual dimorphism in both thymic NA level and thymocyte surface density of $\beta_{2}$-ARs, which may be responsible for sexual dimorphism in many thymic indices. Moreover, it is clear that CA modulation of thymopoiesis exhibits a significant degree of GCdependent plasticity. At the present time, it is not clear what is relationship among neural, endocrine and locally synthesized CAs in T-cell development modulation.
Furthermore, putative significance of sexual dimorphism in NA levels and AR thymic cell densities for sexual dimorphism in immune response should be established. In addition, the relationship among circulating GCs and locally synthesized GCs and CAs is not understood. Finally, further work is required to clarify the influence of naturally occurring or drug-induced variance in thymic CA action on GC-mediated modulation of T-cell development.

\section{Conflict of Interest}

There is no conflict of interest.

\section{Acknowledgements}

This work was supported by grant number 145049 from the Ministry of Science and Technological development of the Republic of Serbia.

\section{References}

ALANIZ RC, THOMAS SA, PEREZ-MELGOSA M, MUELLER K, FARR AG, PALMITER RD, WILSON CB: Dopamine $\beta$-hydroxylase deficiency impairs cellular immunity. Proc Natl Acad Sci USA 96: 2274-2278, 1999.

ANAGNOSTOU VK, DOUSSIS-ANAGNOSTOPOULOU I, TINIAKOS DG, KARANDREA D, AGAPITOS E, KARAKITSOS P, KITTAS C: Ontogeny of intrinsic innervation in the human thymus and spleen. J Histochem Cytochem 55: 813-820, 2007.

ANDREASSI JL, EGGLESTON WB, STEWART JK: Phenylethanolamine N-methyltransferase mRNA in rat spleen and thymus. Neurosci Lett 241: 75-78, 1998.

ANGLIN JC, BROOKS VL: Tyrosine hydroxylase and norepinephrine transporter in sympathetic ganglia of female rats vary with reproductive state. Auton Neurosci 105: 8-15, 2003.

ANSAR-AHMED S, HISSONG BD, VERTHELYI D, DONNER K, BECKER K, KARPUZOGLU-SAHIN E: Gender and risk of autoimmune diseases: possible role of estrogenic compounds. Environ Health Perspect 107 (Suppl 5): 681-686, 1999.

BAO JY, HUANG Y, WANG F, PENG YP, QIU YH: Expression of alpha-AR subtypes in T lymphocytes and role of the alpha-ARs in mediating modulation of T cell function. Neuroimmunomodulation 14: 344-353, 2007.

BATANERO E, DE LEEUW FE, JANSEN GH, VAN WICHEN DF, HUBER J, SCHUURMAN HJ: The neural and neuro-endocrine component of the human thymus: II. Hormone immunoreactivity. Brain Behav Immun 6: 249264, 1992.

BELLINGER DL, MILLAR BA, PEREZ S, CARTER J, WOOD C, THYAGARAJAN S, MOLINARO C, LUBAHN C, LORTON D: Sympathetic modulation of immunity: relevance to disease. Cell Immunol 252: 27-56, 2008.

BERGQUIST J, TARKOWSKI A, EKMAN R, EWING A: Discovery of endogenous catecholamines in lymphocytes and evidence for catecholamine regulation of lymphocyte function via an autocrine loop. Proc Natl Acad Sci USA 91: 12912-12916, 1994.

BERGQUIST J, JOSEFSSON E, TARKOWSKI A, EKMAN R, EWING A: Measurements of catecholaminemediated apoptosis of immunocompetent cells by capillary electrophoresis. Electrophoresis 18: 1760-1766, 1997.

BERGQUIST J, OHLSSON B, TARKOWSKI A: Nuclear factor-kappa B is involved in the catecholaminergic suppression of immunocompetent cells. Ann NY Acad Sci 917: 281-289, 2000.

BESEDOVSKY HO, DEL REY A: Immune-neuro-endocrine interactions: facts and hypotheses. Endocr Rev 17: 64-93, 1996.

BLALOCK JE: The syntax of immune-neuroendocrine communication. Immunol Today 15: 504-511, 1994. 
BLAZKOVEC AA, ORSINI MW: Ontogenic aspects of sexual dimorphism and the primary immune response to sheep erythrocytes in hamsters from prepuberty to senescence. Int Arch Allergy Appl Immunol 50: 55-67, 1976.

BOTHAM CA, JONES GV, KENDALL MD: Immuno-characterisation of neuroendocrine cells of the rat thymus gland in vitro and in vivo. Cell Tissue Res 303: 381-389, 2001.

BURKE WJ, KRISTAL BS, YU BP, LI SW, LIN TS: Norepinephrine transmitter metabolite generates free radicals and activates mitochondrial permeability transition: a mechanism for DOPEGAL induced apoptosis. Brain Res 787: 328-332, 1998.

CAVALLOTTI C, ARTICO M, CAVALLOTTI D: Occurrence of adrenergic nerve fibers and of noradrenaline in thymus gland of juvenile and aged rats. Immunol Lett 70: 53-62, 1999.

COSENTINO M, BOMBELLI R, FERRARI M, MARINO F, RASINI E, MAESTRONI GJM, CONTI A, BOVERI M, LECCHINI S, FRIGO G: HPLC-ED measurement of endogenous catecholamines in human immune cells and hematopoietic cell lines. Life Sci 68: 283-295, 2000.

COSENTINO M, MARINO F, BOMBELLI R, FERRARI M, LECCHINI S, FRIGO G: Unravelling dopamine (and catecholamine) physiopharmacology in lymphocytes: open questions. Trends Immunol 24: 581-582; author reply 582-583, 2003.

COTECCHIA S, DE BLASI A: Glucocorticoids increase $\beta$-adrenoceptors on human intact lymphocytes in vitro. Life Sci 35: 2359-2364, 1984.

CUNNICK JE, LYSLE DT, KUCINSKI BJ, RABIN BS: Evidence that shock-induced immune suppression is mediated by adrenal hormones and peripheral beta-adrenergic receptors. Pharmacol Biochem Behav 36: 645-651, 1990.

DA SILVA JAP: Sex hormones and glucocorticoids: interactions with the immune system. Ann N Y Acad Sci 876: 102$117,1999$.

DARDENNE M, SAVINO W: Interdependence of the endocrine and immune systems. Adv Neuroimmunol 6: 297-307, 1996.

DOBBS CM, VASQUEZ M, GLASER R, SHERIDAN JF: Mechanisms of stress-induced modulation of viral pathogenesis and immunity. J Neuroimmunol 48: 151-160, 1993.

DURANT S: In vivo effects of catecholamines and glucocorticoids on mouse thymic cAMP content and thymolysis. Cell Immunol 102:136-143, 1986.

ELENKOV IJ, WILDER RL, CHROUSOS GP, VIZI ES: The sympathetic nerve - an integrative interface between two supersystems: the brain and the immune system. Pharmacol Rev 52: 595-638, 2000.

FABRIS N, MOCCHEGIANI E, PROVINCIALI M: Plasticity of neuroendocrine-thymus interactions during aging. Exp Gerontol 32: 415-429, 1997.

FELTEN DL, FELTEN SY, CARLSON SL, OLSCHOWKA JA, LIVNAT S: Noradrenergic and peptidergic innervation of lymphoid tissue. J Immunol 135: 755s-765s, 1985.

FUCHS BA, ALBRIGHT JW, ALBRIGHT JF: $\beta$-adrenergic receptors on murine lymphocytes: density varies with cell maturity and lymphocyte subtype and is decreased after antigen administration. Cell Immunol 114: 231-245, 1988.

GALBIATI F, BASSO V, CANTUTI L, GIVOGRI MI, LOPEZ-ROSAS A, PEREZ N, VASU C, CAO H, VAN BREEMEN R, MONDINO A, BONGARZONE ER: Autonomic denervation of lymphoid organs leads to epigenetic immune atrophy in a mouse model of Krabbe disease. J Neurosci 27: 13730-13738, 2007.

HADDAD JJ: On the mechanisms and putative pathways involving neuroimmune interactions. Biochem Biophys Res Commun 370: 531-535, 2008.

HAGERTY T, FERNANDEZ E, LYNCH K, WANG SS, MORGAN WW, STRONG R: Interaction of a glucocorticoid-responsive element with regulatory sequences in the promoter region of the mouse tyrosine hydroxylase gene. J Neurochem 78: 1379-88, 2001.

HASKO G, ELENKOV IL, VIZI ES: Presynaptic receptors involved in the modulation of release of noradrenaline from the sympathetic nerve terminals of the rat thymus. Immunol Lett 47: 133-137, 1995.

HEAD GM, MENTLEIN R, VON PATAY B, DOWNING JEG, KENDALL MD: Neuropeptides exert direct effects on rat thymic epithelial cells in culture. Dev Immunol 6: 95-104, 1998. 
HUEBER AO, BERNARD AM, BATTARI CL, MARGUET D, MASSOL P, FOA C, BRUN N, GARSIA S, STEWARD C, PIERRES M, HE HT: Thymocytes in Thy-1-/- mice show augmented TCR signaling and impaired differentiation. Curr Biol 7: 705-708, 1997.

JIANG JL, QIU YH, PENG YP, WANG JJ: Immunoregulatory role of endogenous catecholamines synthesized by immune cells. Acta Physiol Sin 58: 309-317, 2006.

JONES GV, BOTHAM CA, CLARKE AG, KENDALL MD: Immunoreactivity of neural crest-derived cells in thymic tissue developing under the rat kidney capsule. Brain Behav Immun 12: 163-180, 1998.

JOSEFSSON E, BERGQUIST J, EKMAN R, TARKOWSKI A: Catecholamines are synthesized by mouse lymphocytes and regulate function of these cells by induction of apoptosis. Immunology 88: 140-146, 1996.

KAVELAARS A: Regulated expression of $\alpha-1$ adrenergic receptors in the immune system. Brain Behav Immun 16: 799-807, 2002.

KILLEEN N: Thy-1-hiding in full view. Curr Biol 7: R774-R777, 1997.

KOVACS WJ, OLSEN NJ: Sex hormones and immune responses. In: Contemporary Endocrinology: Autoimmune Endocrinopathies. R VOLPE (ed), Humana Press Inc, Totowa, 1998, pp 163-181.

KRANZ A, KENDALL MD, VON GAUDECKER B: Studies on rat and human thymus to demonstrate immunoreactivity of calcitonin gene-related peptide, tyrosine hydroxylase and neuropeptide Y. J Anat 191: 441-450, 1997.

KURZ B, FEINDT J, VON GAUDECKER B, KRANZ A, LOPPNOW H, MENTLEIN R: $\beta$-adrenoceptor-mediated effects in rat cultured thymic epithelial cells. Br J Pharmacol 120: 1401-1408, 1997.

LECHNER O, WIEGERS GJ, OLIVEIRA-DOS-SANTOS AJ, DIETRICH H, RECHEIS H, WATERMAN M, BOYD R, WICK G: Glucocorticoid production in the murine thymus. Eur J Immunol 30: 337-346, 2000.

LEPOSAVIĆ G, MIĆIĆ M, UGREŠIĆ N, BOGOJEVIĆ M, ISAKOVIĆ K: Components of sympathetic innervation of the rat thymus during late fetal and postnatal development: histofluorescence and biochemical study. Thymus 19: 77-87, 1992.

LEPOSAVIĆ G, KARAPETROVIĆ B, OBRADOVIĆ S, VIDIĆ-DANKOVIĆ B, KOSEC D: Differential effects of gonadectomy on the thymocyte phenotypic profile in male and female rats. Pharmacol Biochem Behav 54: 269-276, 1996.

LEPOSAVIĆ G, PLEĆAŠ B, KOSEC D: Differential effects of chronic propranolol treatment on the phenotypic profile of thymocytes from immature and adult rats. Immunopharmacology 46: 79-87, 2000.

LEPOSAVIĆ G, ARSENOVIĆ-RANIN N, RADOJEVIĆ K, KOSEC D, PEŠIĆ V, VIDIĆ-DANKOVIĆ B, PLEĆAS̆SOLAROVIĆ B, PILIPOVIĆ I: Characterization of thymocyte phenotypic alterations induced by long-lasting beta-adrenoceptor blockade in vivo and its effects on thymocyte proliferation and apoptosis. Mol Cell Biochem 285: 87-99, 2006.

LEPOSAVIĆ G, RADOJEVIĆ K, VIDIĆ-DANKOVIĆ B, KOSEC D, PILIPOVIĆ I, PERIŠIĆ M: Early postnatal castration affects thymic and thymocyte noradrenaline levels and $\beta$-adrenoceptor-mediated influence on the thymopoiesis in adult rats. $J$ Neuroimmunol 182: 100-115, 2007.

LEPOSAVIĆ G, PILIPOVIĆ I, RADOJEVIĆ K, PEŠIĆ V, PERIŠIĆ M, KOSEC D: Catecholamines as immunomodulators: a role for adrenoceptor-mediated mechanisms in fine tuning of T-cell development. Auton Neurosci 144: 1-12, 2008.

LEPOSAVIĆ G, PEŠIĆ V, STOJIĆ-VUKANIĆ Z, RADOJEVIĆ K, ARSENOVIĆ-RANIN N, KOSEC D, PERIŠIĆ M, PILIPOVIĆ I: Age-associated plasticity of $\alpha 1$-adrenoceptor-mediated tuning of T-cell development. Exp Gerontol 45: 918-935, 2010.

MADDEN KS, FELTEN DL: Experimental basis for neural-immune interactions. Physiol Rev 75: 77-106, 1995.

MADDEN KS, FELTEN DL: $\beta$-adrenoceptor blockade alters thymocyte differentiation in aged mice. Cell Mol Biol 47: 189-196, 2001.

MARCHETTI B, MORALE MC, PELLETIER G: The thymus gland as a major target for the central nervous system and the neuroendocrine system: neuroendocrine modulation of thymic $\beta 2$-adrenergic receptor distribution as revealed by in vitro autoradiography. Mol Cell Neurosci 1: 10-19, 1990a. 
MARCHETTI B, MORALE MC, PELLETIER G: Sympathetic nervous system control of thymus gland maturation: autoradiographic characterization and localization of the beta2-adrenergic receptors in the rat thymus gland and presence of a sexual dimorphism during ontogenic development. Prog Neuroendocrinimmunol 3: 103-115, 1990 b.

MARCHETTI B, MORALE MC, PARADIS P, BOUVIER M: Characterization, expression, and hormonal control of a thymic beta 2-adrenergic receptor. Am J Physiol 267: E718-E731, 1994.

MARRACK P, KAPPLER J: The T-cell repertoire for antigen and MHC. Immunol Today 9: 308-315, 1988.

MCCORMACK JE, WADE T, MORALES H, KAPPLER J, MARRACK P: Analysis of class II MHC structure in thymic nurse cells. Cell Immunol 138: 413-422, 1991.

MELVIN JE, HAMILL RW: Gonadal hormone regulation of neurotransmitter synthesizing enzymes in the developing hypogastric ganglion. Brain Res 383: 38-46, 1986.

MELVIN JE, HAMILL RW: The major pelvic ganglion: androgen control of postnatal development. J Neurosci 7 : 1607-1612, 1987.

MOCCHEGIANI E, SANTARELLI L, COSTARELLI L, CIPRIANO C, MUTI E, GIACCONI R, MALAVOLTA M: Plasticity of neuroendocrine-thymus interactions during ontogeny and ageing: role of zinc and arginine. Ageing Res Rev 5: 281-309, 2006.

MORA F, LEE TF, MYERS RD: Involvement of alpha- and beta-adrenoreceptors in the central action of norepinephrine on temperature, metabolism, heart and respiratory rates of the conscious primate. Brain Res Bull 11: 613-616, 1983.

NANCE DM, SANDERS VM: Autonomic innervation and regulation of the immune system (1987-2007). Brain Behav Immun 21: 736-745, 2007.

NOVOTNY GEK, SOMMERFELD H, ZIRBES T: Thymic innervation in the rat: a light and electron microscopical study. J Comp Neurol 302: 552-561, 1990.

PEŠIĆ V, PLEĆAŠ-SOLAROVIĆ B, RADOJEVIĆ K, KOSEC D, PILIPOVIĆ I, PERIŠIĆ M, LEPOSAVIĆ G: Longterm beta-adrenergic receptor blockade increases levels of the most mature thymocyte subsets in aged rats. Int Immunopharmacol 7: 674-686, 2007.

PEŠIĆ V, KOSEC D, RADOJEVIĆ K, PILIPOVIĆ I, PERIŠIĆ M, VIDIĆ-DANKOVIĆ B, LEPOSAVIĆ G: Expression of $\alpha 1$-adrenoceptors on thymic cells and their role in fine tuning of thymopoiesis. $J$ Neuroimmunol 214: 55-66, 2009.

PEZZANO M, SAMMS M, MARTINEZ M, GUYDEN J: Questionable thymic nurse cell. Microbiol Mol Biol Rev 65: 390-403, 2001.

PILIPOVIĆ I, VIDIĆ-DANKOVIĆ B, PERIŠIĆ M, RADOJEVIĆ K, ČOLIĆ M, TODOROVIĆ V, LEPOSAVIĆ G: Sexual dimorphism in the catecholamine-containing thymus microenvironment: a role for gonadal hormones. J Neuroimmunol 195: 7-20, 2008.

PILIPOVIĆ I, KOSEC D, RADOJEVIĆ K, PERIŠIĆ M, PEŠIĆ V, STOJIĆ-VUKANIĆ Z, LEPOSAVIĆ G: Glucocorticoids, master modulators of the thymic catecholaminergic system? Braz J Med Biol Res 43: 279$284,2010$.

PLEĆAŠ-SOLORAVIĆ B, HRISTIĆ-ŽIVKOVIĆ I, RADOJEVIĆ K, KOSEC D, LEPOSAVIĆ G: Chronic alpha1adrenoreceptor blockade produces age-dependent changes in rat thymus structure and thymocyte differentiation. Histol Histopathol 20: 833-841, 2005.

QIAO S, OKRET S, JONDAL M: Thymocyte-synthesized glucocorticoids play a role in thymocyte homeostasis and are downregulated by adrenocorticotropic hormone. Endocrinology 150: 4163-4169, 2009.

QIU YH, CHENG C, DAI L, PENG YP: Effect of endogenous catecholamines in lymphocytes on lymphocyte function. J Neuroimmunol 167: 45-52, 2005.

RAUŠKI A, KOSEC D, VIDIĆ-DANKOVIĆ B, PLEĆĂ̌S-SOLAROVIĆ B, LEPOSAVIĆ G: Effects of betaadrenoceptor blockade on the phenotypic characteristics of thymocytes and peripheral blood lymphocytes. Int $J$ Neurosci 113: 1653-1673, 2003a.

RAUŠKI A, KOSEC D, VIDIĆ-DANKOVIĆ B, RADOJEVIĆ K, PLEĆAŠ-SOLAROVIĆ B, LEPOSAVIĆ G: Thymopoiesis following chronic blockade of $\beta$-adrenoceptors. Immunopharmacol Immunotoxicol 25: 513-528, $2003 b$. 
RESCO JA, FEDER HH, GOY RW: Androgen concentrations in plasma and testis of developing rats. $J$ Endocrinol 40: 485-491, 1968.

ROKOSH DG, STEWART AFR, CHANG KC, BAILEY BA, KARLINER JS, CAMACHO SA, LONG CS, SIMPSON PC: Alpha(1)-Adrenergic receptor subtype mRNAs are differentially regulated by alpha(1)adrenergic and other hypertrophic stimuli in cardiac myocytes in culture and in vivo. Repression of alpha1B and alpha1D but induction of alpha1C. J Biol Chem 271: 5839-5843, 1996.

SILVA AB, AW D, PALMER DB: Evolutionary conservation of neuropeptide expression in the thymus of different species. Immunology 118: 131-140, 2006.

SINGH U: Effect of sympathectomy on the maturation of fetal thymocytes grown within the anterior eye chambers in mice. Adv Exp Biol Med 186: 349-356, 1985a.

SINGH U: Lymphopoiesis in the nude fetal thymus following sympathectomy. Cell Immunol 93: 222-228, 1985b.

STEVENSON JR, WESTERMANN J, LIEBMANN PM, HÖRTNER M, RINNER I, FELSNER P, WÖLFLER A, SCHAUENSTEIN K: Prolonged alpha-adrenergic stimulation causes changes in leukocyte distribution and lymphocyte apoptosis in the rat. J Neuroimmunol 120: 50-57, 2001.

STOJIĆ-VUKANIĆ Z, RAUŠKI A, KOSEC D, RADOJEVIĆ K, PILIPOVIĆ I, LEPOSAVIĆ G: Dysregulation of T-Cell development in adrenal glucocorticoid-deprived rats. Exp Biol Med 234: 1067-1074, 2009.

THOENEN H, BARDE YA: Physiology of nerve growth factor. Physiol Rev 60: 1284-1335, 1980.

THYAGARAJAN S, FELTEN DL: Modulation of neuroendocrine-immune signaling by L-deprenyl and L-desmethyldeprenyl in aging and mammary cancer. Mech Ageing Dev 123: 1065-1079, 2002.

VAN DER VOORT R, HEIJNEN CJ, WULFFRAAT N, KUIS W, KAVELAARS A: Stress induces increases in IL-6 production by leucocytes of patients with the chronic inflammatory disease juvenile rheumatoid arthritis: a putative role for alpha(1)-adrenergic receptors. J Neuroimmunol 110: 223-229, 2000a.

VAN DER VOORT R, KAVELAARS A, VAN DE POL M, HEIJNEN CJ: Noradrenaline induces phosphorylation of ERK-2 in human peripheral bloodmononuclear cells after induction of alpha(1)-adrenergic receptors. J Neuroimmunol 108: 82-91, 2000b.

VIZI ES, LABOS E: Nonsynaptic interactions at presynaptic level. Prog Neurobiol 37: 145-163, 1991.

VIZI ES, ORSO E, OSIPENKO ON, HASKO G, ELENKOV IJ: Neurochemical, electrophysiological and immunocytochemical evidence for a noradrenergic link between the sympathetic nervous system and thymocytes. Neuroscience 68: 1263-1276, 1995.

VON PATAY B, KURZ B, MENTLEIN R: Effect of transmitters and co-transmitters of the sympathetic nervous system on interleukin-6 synthesis in thymic epithelial cells. Neuroimmunomodulation 6: 45-50, 1999.

WAJEMAN-CHAO SA, LANCASTER SA, GRAF LH JR, CHAMBERS D: Mechanism of catecholamine-mediated destabilization of messenger RNA encoding Thy-1 protein in T-lineage cells. J Immunol 161: 4825-4833, 1998.

WARTHAN MD, FREEMAN JG, LOESSER KE, LEWIS CW, HONG M, CONWAY CM, STEWART JK: Phenylethanolamine N-methyl transferase expression in mouse thymus and spleen. Brain Behav Immun 16: 493-499, 2002.

WILLIAMS JM, FELTEN DL: Sympathetic innervation ofmurine thymus and spleen: a comparative histofluorescence study. Anat Rec 199: 531-542, 1981.

XI H, SCHWARTZ R, ENGEL I, MURRE C, KERSH GJ: Interplay between RORgammat, Egr3, and E proteins controls proliferation in response to pre-TCR signals. Immunity 24: 813-826, 2006. 